\title{
Movement and habitat use by the spine-tail devil ray in the Eastern Pacific Ocean
}

\author{
Donald A. Croll ${ }^{1, *}$, Kelly M. Newton ${ }^{1}$, Kevin Weng ${ }^{2}$, Felipe Galván-Magaña ${ }^{3}$, \\ John O'Sullivan ${ }^{4}$, Heidi Dewar ${ }^{5}$ \\ ${ }^{1}$ Ecology and Evolutionary Biology Department, University of California Santa Cruz, 100 Shaffer Road, Santa Cruz, \\ California 95060, USA \\ ${ }^{2}$ Pelagic Fisheries Research Program, University of Hawaii at Manoa, 1000 Pope Road, Honolulu, Hawaii 96822, USA \\ ${ }^{3}$ Centro Interdisciplinario de Ciencias Marinas, Apartado Postal 592, La Paz, Baya California Sur, 23096, Mexico \\ ${ }^{4}$ Monterey Bay Aquarium, 886 Cannery Row, Monterey, California 93950, USA \\ ${ }^{5}$ Southwest Fisheries Science Center, 8604 La Jolla Shores Dr., La Jolla, California 92037, USA
}

\begin{abstract}
The devil-ray family Mobulidae (order Myliobatiformes) comprises wide-ranging, pelagic batoids, but little is known about their basic ecology. We present the first data on the longdistance movement of mobulid devil rays. We attached pop-up archival satellite tags to 13 individuals of the spine-tail devil ray Mobula japanica (disk width $199.5 \pm 30.0 \mathrm{~cm}$; mean \pm SD) off Baja California Sur to examine their habitat movement patterns. Tags remained on the rays for $83 \pm 52 \mathrm{~d}($ mean $\pm \mathrm{SD})$. Although their primary prey undergo diel migrations from depths $>100 \mathrm{~m}$ during the day to the surface at night, tagged individuals spent the majority of their time $(89.5 \pm$ $3.1 \%$ during the day and $96.8 \pm 3.5 \%$ at night; mean $\pm \mathrm{SD}$ ) near the surface at a depth of $\leq 50 \mathrm{~m}$ in 20 to $30^{\circ} \mathrm{C}$ water. Thus, $M$. japanica likely forages at night and remains near the surface during the day, where warmer water temperatures likely confer a physiological advantage. Most (8 of 13) individuals moved from the tagging location in the southern Gulf of California to the Pacific coast of Baja California Sur, tracking published records of seasonal patterns in euphausiid abundance, similar to other top predators in the region. The depths and geographic regions occupied by $M$. japanica coincide with the focus of artisanal and industrial fisheries. This overlap with fisheries, when combined with the delayed maturity and low reproductive rates of devil rays, raises concerns of potentially damaging high bycatch mortality.
\end{abstract}

KEY WORDS: Mobulid · Mobula japanica $\cdot$ Manta ray $\cdot$ Elasmobranch $\cdot$ Baja California $\cdot$ Gulf of California $\cdot$ Conservation

\section{INTRODUCTION}

Elasmobranchs of the devil-ray family Mobulidae (order Myliobatiformes) are wide-ranging pelagic batoids of 2 genera (Manta and Mobula), occurring throughout tropical and warm-temperate waters (Eschmeyer et al. 1983, Notarbartolo-di-Sciara 1988). They are filter feeders, using their cephalic lobes to enhance the entrance of plankton into their mouths, and feed almost exclusively on zooplankton, pelagic crustaceans and small forage fishes (Eschmeyer et al. 1983, Notarbartolo-di-Sciara 1988).

All 11 mobulid species are live bearers with low fecundity, giving birth to a single offspring per pregnancy (Notarbartolo-di-Sciara 1988). Because mobulids are taken directly or as bycatch in a range of fisheries (White et al. 2006), they are particularly vulnerable to overexploitation. Eight of the 11 mob- 
ulid species reviewed on the IUCN Red List are listed as near-threatened or above, with the remaining 3 species listed as data deficient (IUCN 2012). Five mobulid species occur in the Gulf of California, Mexico and along the Pacific Coast of the Baja California, Mexico Peninsula: Mobula japanica, M. munkiana, M. tarapacana, M. thurstoni and Manta birostris (Eschmeyer et al. 1983, Notarbartolo-diSciara 1988, Villavicencio-Garayzar 1991). However, little is known about their ecology, population biology and movement patterns (Notarbartolo-di-Sciara 1988), thus limiting the ability of fishery managers to protect mobulids.

Since the early 1980s, the artisanal mobulid fishery in the Gulf of California has focussed on Mobula japanica (Notarbartolo-di-Sciara 1988, SerranoLópez 2009). Recognizing the vulnerability of mobulids to overexploitation, the Mexican government enacted fisheries legislation prohibiting their targeted take in 2005 (NOM-029-PESC 2004); however, illegal and non-target bycatch still occurs (Bizzarro et al. 2009).

Mobula japanica has a specialized diet in the Gulf of California, comprising almost exclusively the euphausiid Nyctiphanes simplex (Notarbartolo-diSciara 1988, Sampson et al. 2010). Aggregations of $M$. japanica appear in the vicinity of La Paz, Baja California Sur, during spring, corresponding with seasonal patterns of krill abundance (Gómez-Gutiérrez et al. 2010). However, local fishers report that $M$. japanica move out of the Gulf of California by the end of summer, with large adults being rare during winter (Notarbartolo-di-Sciara 1988, Hobro 2002). Nothing is known about the seasonal distribution of these $M$. japanica from late summer through winter when they are not available to fishers. We give the first information on the seasonal migration, diel movement patterns and temperature preferences of M. japanica, as well as on the implications of these data for $M$. japanica fishery management.

\section{MATERIALS AND METHODS}

\section{Capture and satellite telemetry}

Mobula japanica were captured in the early summer (June) in the vicinity of La Paz, Baja California Sur, Mexico $\left(24.8^{\circ} \mathrm{N}, 110.5^{\circ} \mathrm{W}\right)$, from 2004 to 2007. Working with local fishers, individuals were captured with encircling surface nets $150 \mathrm{~m}$ long, $15 \mathrm{~m}$ deep, with $25 \mathrm{~cm}$ mesh. Once captured, individuals were kept in the water alongside the skiff, and mea- sured for length and half-width, sexed and biopsied for DNA analysis.

Pop-up satellite archival tags (PAT tag hardware version 2 during 2004-2005 and MK10-PAT tag version 10 during 2006-2007; Wildlife Computers) were secured to the dorsal surface of the ray along the pectoral fin margin using a medical-grade plastic umbrella dart with a $10 \mathrm{~cm}$ segment of $136 \mathrm{~kg}$ monofilament line applied with an aluminum pole. We applied a secondary attachment loop from the base of the PAT tag float to the dorsal surface of the animal to keep the tag flush with the surface of the animal along the margin of the pectoral fin.

PAT tags recorded temperature, depth and light intensity data while attached to the ray, and on a preprogrammed date, released to float to the surface and transmitted summary data to Argos modules on NOAA weather satellites (Block et al. 1998a). PAT tags were programmed to archive data at $30 \mathrm{~s}$ intervals in 2004-2005 and at 15 s intervals during 20062007. In the event that tags were physically recovered, this archive could be downloaded to a computer. Otherwise, tags transmitted a summary of the archival record comprising histograms of temperature and depth occupancy, depth-temperature profiles, and light curves for dawn and dusk of each day. These summaries were calculated for $12 \mathrm{~h}$ intervals in 2004-2005 and for $6 \mathrm{~h}$ intervals in 2006-2007.

\section{Data analysis}

We determined a length-width relationship for Mobula japanica based on our measurements. The literature on rays typically presents disc width; however, this is difficult to measure on live individuals alongside a skiff. Therefore, we either measured length (to the tip of the pelvic fin) and later estimated width using a linear regression, or we measured the half-width of the animal from the midline vertebrae to the tip of one pectoral fin.

Light levels can be used to estimate longitude (Hill 1994, Hill \& Braun 2001, Ekstrom 2002), and associated latitudes can be estimated by comparing sea surface temperature (SST) recorded by tags in situ with that obtained from satellites (Teo et al. 2004, Nielsen et al. 2006). We used light measurements recorded by PAT tags to estimate longitude using proprietary software provided by the tag manufacturers (GPE-Suite version 1.02.0002, Wildlife Computers). To obtain associated latitudes, we used the SST-matching method of Teo et al. (2004) implemented in MATLAB (The MathWorks). Light- 
and/or SST-based geolocation for free-ranging marine vertebrates provides daily positions with errors on the order of $100 \mathrm{~km}$ (DeLong et al. 1992, Gunn et al. 1994, Block et al. 1998b, Welch \& Eveson 1999, Musyl et al. 2001, Teo et al. 2004). We estimated geolocation errors by comparing the results from light and/or SST methods with known deployment locations recorded by GPS (root meansquare [RMS] error $<0.01 \mathrm{~km}$; Wormley 2007), or pop-up positions obtained from Argos with location qualities of 2 or 3 (RMS error $<0.35 \mathrm{~km}$; www. argos-system.org).

The geographic habitat usage of Mobula japanica was estimated using the kernel density technique (Silverman 1986), embedded in the Animal Movement extension (Hooge \& Eichenlaub 1997) for ArcView 3.2 (ESRI). Vertical habitat use by M. japanica was quantified using the average distributions of time at depth and temperature transmitted by the PAT tags. Tags defined day as 06:00-18:00 h local time (GMT $-6 \mathrm{~h}$ ) and night as 18:00-06:00 h. During the course of the study, the actual time of sunrise and sunset at the tagging location varied from 05:3207:05 $\mathrm{h}$ and 17:41-19:13 $\mathrm{h}$, respectively (16 June26 December; US Naval Observatory, http://aa.usno. navy.mil/data/docs/RS_OneDay.html). Ocean depth at the locations where tags popped up was determined based on the ETOPO2 bathymetry data set (National Geophysical Data Center 2001) using the M_Map package (Pawlowicz 2006) for MATLAB. Results are presented as means \pm SD unless otherwise stated.

\section{RESULTS}

Details of the 13 Mobula japanica (10 males, 3 females) tagged during June of $4 \mathrm{yr}$ with PAT tags are presented in Table 1.

\section{Length-width relationship}

The length-width relationship of Mobula japanica was determined based on our measurements (9 males, 3 females, 50 to $104 \mathrm{~cm}$ disc length). The best fit $\left(r^{2}=0.97\right)$ was obtained with a linear regression given by width $=2.1378 \times$ length -0.8826 , and this equation was used to estimate disc width for individuals where only length was measured. Mean disc length was $93.7 \pm 13.3 \mathrm{~cm}$, giving an estimated mean disc width of $199.5 \pm 30.0 \mathrm{~cm}$ (Table 1). Based upon an estimate at which the onset of sexual maturity occurs (Notarbartolo-di-Sciara 1988, Serrano-López 2009), 7 rays (5 males, 2 females) were sexually mature.

\section{Depth and temperature utilization}

The movement and depth utilization profiles of a typical Mobula japanica (Mx06-14) are shown in Fig. 1. Tagged Mobula japanica stayed almost always in the upper $50 \mathrm{~m}$ of the water column, $89.5 \pm$ $3.1 \%$ of time during the day and $96.8 \pm 3.5 \%$ at night (Fig. 2a), and spent over half their time in the upper $5 \mathrm{~m}, 50.5 \pm 7.3 \%$ during the day and $63.3 \pm 6.2 \%$ at

Table 1. Mobula japanica. Characteristics of tagged individuals in the southern Gulf of California. Depths at start $150 \pm 87 \mathrm{~m}$. ID: identification; M: male, F: female

\begin{tabular}{|c|c|c|c|c|c|c|c|c|c|c|c|}
\hline \multirow[t]{2}{*}{ Ray ID } & \multirow[t]{2}{*}{ Sex } & \multicolumn{2}{|c|}{ Disc $\_$} & \multicolumn{2}{|c|}{ D Date $\_$} & \multirow[t]{2}{*}{ Days } & \multicolumn{2}{|c|}{- Start } & \multicolumn{2}{|c|}{ End $\longrightarrow$} & \multirow{2}{*}{$\begin{array}{c}\text { End } \\
\text { depth } \\
\text { (m) }\end{array}$} \\
\hline & & $\begin{array}{l}\text { length } \\
\text { (cm) }\end{array}$ & $\begin{array}{l}\text { width } \\
(\mathrm{cm})\end{array}$ & Tagging & Pop-up & & $\begin{array}{c}\text { latitude } \\
\left({ }^{\circ} \mathrm{N}\right)\end{array}$ & $\begin{array}{c}\text { longitude } \\
\left({ }^{\circ} \mathrm{W}\right)\end{array}$ & $\begin{array}{c}\text { latitude } \\
\left({ }^{\circ} \mathrm{N}\right)\end{array}$ & $\begin{array}{c}\text { longitude } \\
\left({ }^{\circ} \mathrm{W}\right)\end{array}$ & \\
\hline $\mathrm{Mx} 042^{\mathrm{a}}$ & $\mathrm{M}$ & 102 & $217^{\mathrm{b}}$ & 17 Jun 04 & 31 Jul 04 & 44 & 24.83 & 110.53 & 22.56 & 110.12 & -2990 \\
\hline $\mathrm{Mx} 053^{\mathrm{a}}$ & $\mathrm{F}$ & 109 & $232^{\mathrm{b}}$ & 18 Jun 05 & $1 \mathrm{Dec} 05$ & 166 & 24.83 & 110.53 & 20.11 & 110.05 & -2748 \\
\hline Mx05_5 $5^{\mathrm{a}}$ & M & 112 & $238^{\mathrm{b}}$ & 21 Jun 05 & 26 Dec 05 & 188 & 24.84 & 110.53 & 20.29 & 111.48 & -3267 \\
\hline $\mathrm{Mx} 054^{\mathrm{a}}$ & $\mathrm{F}$ & 103 & $219^{b}$ & 21 Jun 05 & 4 Aug 05 & 44 & 24.84 & 110.53 & 24.25 & 111.60 & -202 \\
\hline Mx05_20 & M & 100 & $212^{\mathrm{b}}$ & 23 Jun 05 & 23 Oct 05 & 122 & 24.84 & 110.53 & 21.89 & 111.19 & -3242 \\
\hline Mx06_11 & M & 85 & 186 & 14 Jun 06 & 19 Aug 06 & 66 & 24.90 & 110.51 & 26.39 & 109.97 & -718 \\
\hline Mx06_12 & M & 87 & 196 & 14 Jun 06 & 7 Aug 06 & 54 & 24.90 & 110.51 & 22.21 & 109.81 & -3156 \\
\hline Mx06_14 & M & 104 & 224 & 14 Jun 06 & 7 Sep 06 & 85 & 24.91 & 110.50 & 26.58 & 113.49 & -57 \\
\hline Mx06_17 & M & 78 & 160 & 17 Jun 06 & $1 \mathrm{Jul} 06$ & 14 & 24.91 & 110.52 & 26.31 & 109.66 & -390 \\
\hline Mx06_22 & M & 84 & 178 & 18 Jun 06 & $23 \mathrm{Sep} 06$ & 97 & 24.91 & 110.50 & 25.05 & 109.43 & -1494 \\
\hline Mx07_17 & M & 101 & 220 & 21 Jun 07 & 9 Sep 07 & 80 & 24.74 & 110.65 & 23.06 & 110.69 & -1433 \\
\hline Mx07_32 & $\mathrm{F}$ & 86 & 170 & 25 Jun 07 & 21 Jul 07 & 26 & 24.75 & 110.65 & 24.38 & 110.68 & -22 \\
\hline Mx07_33 & M & 68 & 142 & 25 Jun 07 & $23 \mathrm{Sep} 07$ & 90 & 24.74 & 110.66 & 26.00 & 111.11 & -26 \\
\hline
\end{tabular}



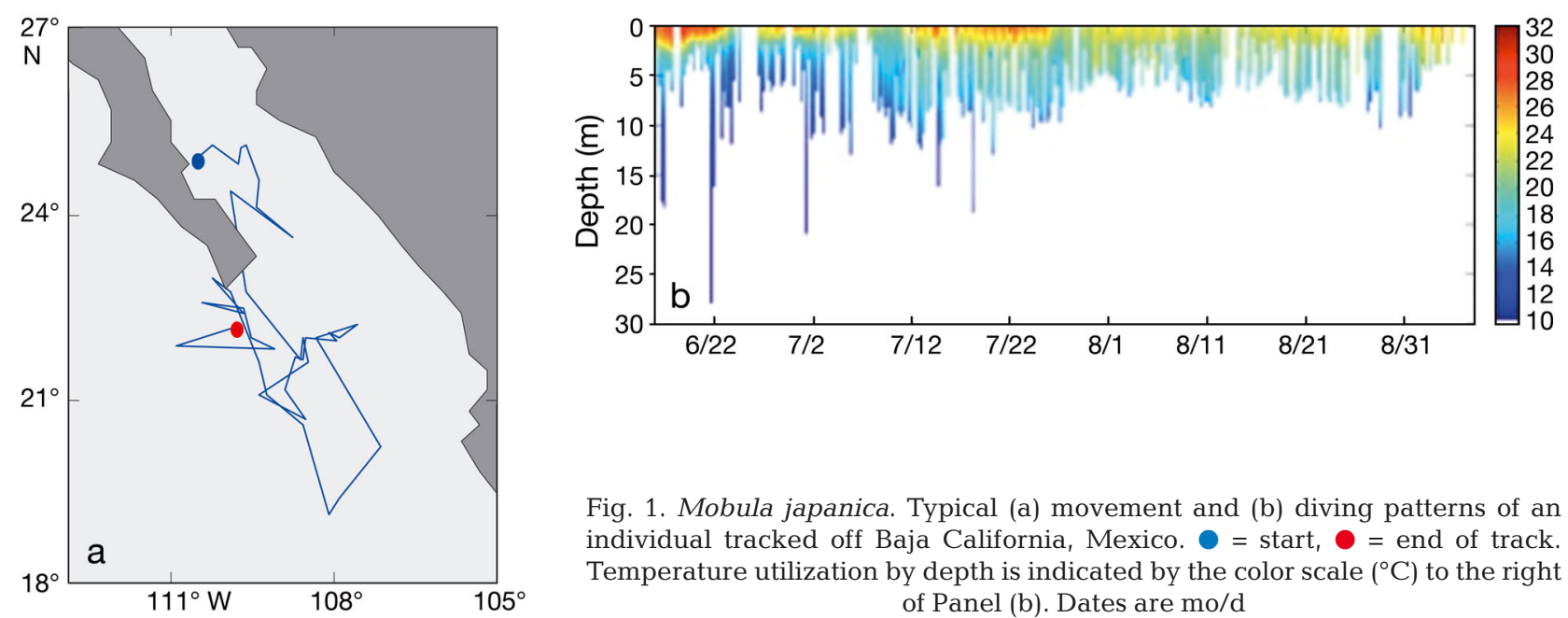

night. As a result, $M$. japanica spent $80.7 \pm 1.8 \%$ of daylight and $87 \pm 2.8 \%$ of nighttime hours in relatively warm water between 20 and $30^{\circ} \mathrm{C}$ (Fig. 2b).

\section{Geographic movements}

The tracking periods averaged $83 \pm 52 \mathrm{~d}$, with a maximum of $188 \mathrm{~d}$, for a total of $1076 \mathrm{~d}$. Most individuals moved from the southern Gulf of California (where tagging occurred) to the Pacific coast of Baja California Sur as summer progressed. The mean depth of the water where rays were tagged was 150 $\pm 87 \mathrm{~m}$; at the end of their tracks it was $1515 \pm 1378 \mathrm{~m}$ depth, indicating that the individuals tended to move from nearshore coastal habitat in the Gulf to offshore neritic or pelagic habitat on the Pacific side during the tracking period. Three rays ended their tracks in shelf waters shallower than $200 \mathrm{~m}, 3$ on slope waters of 200 to $1000 \mathrm{~m}$ and 7 in pelagic waters deeper than $1000 \mathrm{~m}$. Dispersal from the tagging location was not rapid. Kernel density analysis shows that the 50\% core region of occupancy was centered in the La Paz area during June, with the individuals slowly moving out of the Gulf of California, west around the Baja California Peninsula and then north into Bahia Ulloa as the summer progressed (Fig. 3).

\section{DISCUSSION}

\section{Vertical habitat and behavior}

Mobula japanica inhabits tropical and subtropical waters, such that its surface environment is primarily warmer than $20^{\circ} \mathrm{C}$. Notarbartolo-di-Sciara (1988) found that $M$. japanica feed almost exclusively upon the euphausiid Nyctiphanes simplex. As most euphausiids, $N$. simplex undergoes a diel migration: grazing at the surface at night and aggregating at depths $>50 \mathrm{~m}$ during the day (Brinton 1967). Although $M$. japanica occasionally made short daytime excursions to deeper depths where it encountered waters in the range of $12^{\circ} \mathrm{C}$, individuals spent the majority of their time well above the deep scattering layer both day and night, at depths $<50 \mathrm{~m}$. Thus, it is likely that $M$. japanica feeds primarily at night when their prey undergo a diel migration to the surface (Brinton 1967, Gómez-Gutiérrez et al. 2010). This contrasts with the diving depth of other N. simplex predators in the Gulf of California such as Humboldt squid Dosidicus gigas and fin whales Balaenoptera physalus, which consistently dive to depths $>100 \mathrm{~m}$ (Croll et al. 2001, Gilly et al. 2006) to feed on euphausiids during the day.

It is less clear why Mobula japanica spent extensive periods during the day in waters $<5 \mathrm{~m}$, where their prey are largely absent. Generally these waters are $>25^{\circ} \mathrm{C}$, perhaps providing a thermal advantage for metabolic processes. Mobulid rays have a cranial rete system that likely serves as a counter-current heat exchanger to warm the brain, indicating physiological adaptation for temperature control (Alexander 1996). Temperature can profoundly affect physiological processes in poikilotherms (Hochachka \& Somero 2002) such that behavioral preferences for warmer waters in the upper few meters of the surface have the potential to provide significant physiological advantages to mobulid rays, especially during the daytime when prey are not available in surface waters.

Alternatively, Mobula japanica may have been limited by oxygen availability. The eastern margin of the 


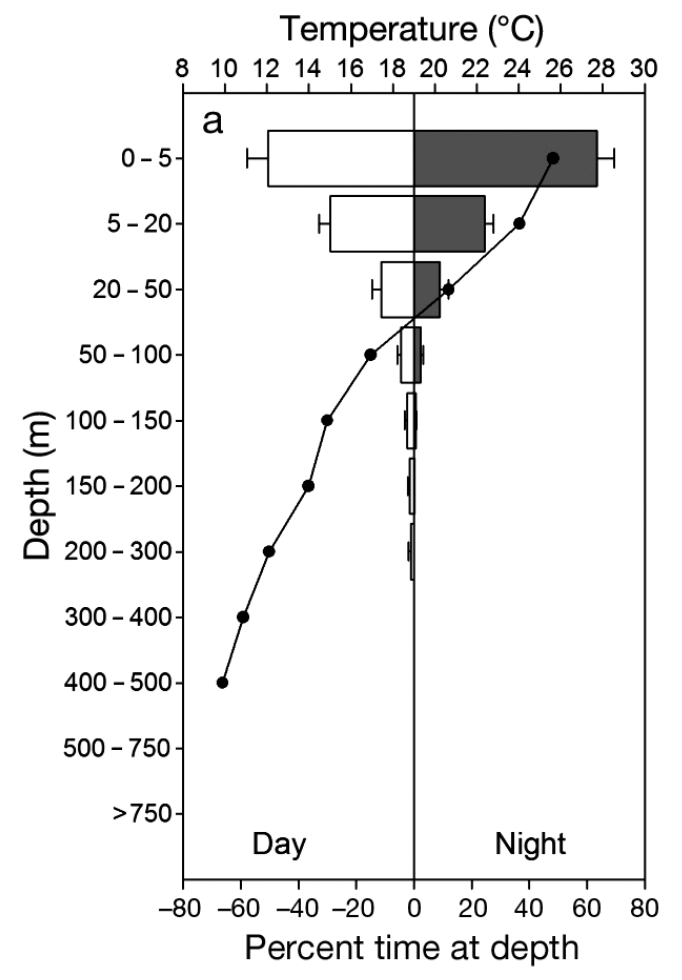

southern Gulf of California has an oxygen minimum as shallow as $150 \mathrm{~m}$ (Lluch-Cota et al. 2007). Airbreathing species such as whales are not limited by the oxygen minimum layer, and some gill-ventilating organisms such as the Humboldt squid have apparently adapted to low oxygen conditions (Gilly et al. 2006). Tagged M. japanica frequently undertook dives deeper than this oxygen minimum layer, indi-

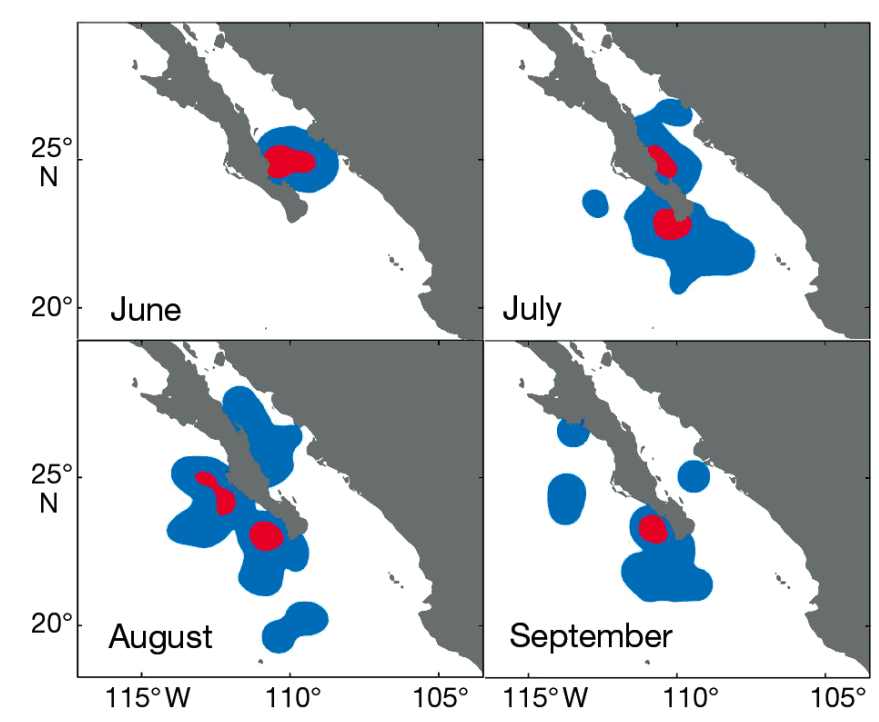

Fig. 3. Mobula japanica. Weighted fixed-kernel density distributions (blue: 95\%; red: 50\%) of 13 tagged individuals, June-September

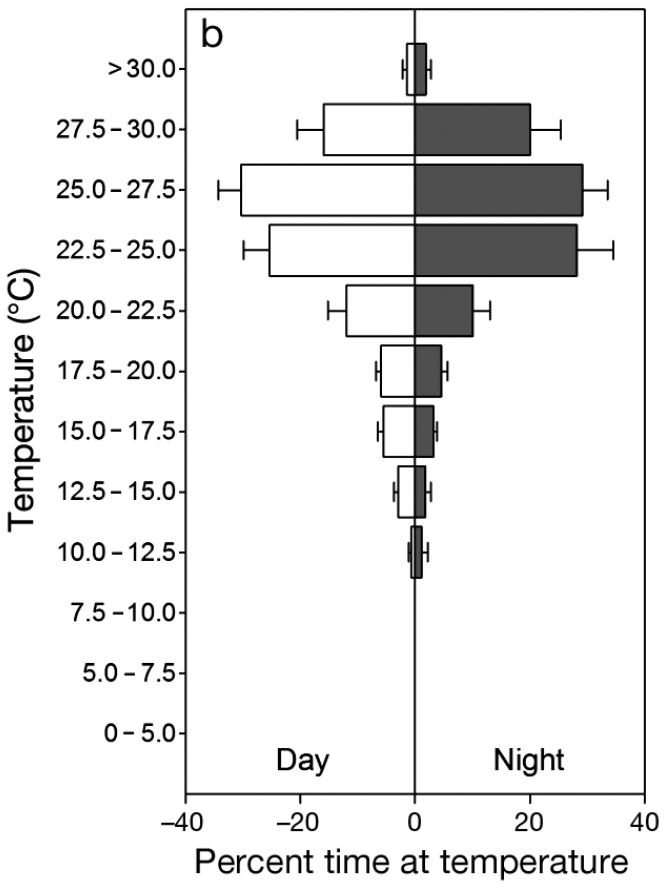

Fig. 2. Mobula japanica. Depth and thermal habitat off Baja California, Mexico. (a) Percent time at depth (bars) during the day (white) and night (gray), and mean temperature at depth (line). (b) Percent time at temperature $\left({ }^{\circ} \mathrm{C}\right)$ during the day (white) and night (gray). Mean $+\mathrm{SE}$ cating that they may be tolerant to limited hypoxia. However, these dives were shorttime, suggesting that they may have incurred an oxygen debt. Temperature at these depths was typically $<15^{\circ} \mathrm{C}$, which may also have been a factor limiting the duration. Whale sharks Rhincodon typus tracked in the Gulf of California similarly spent the majority of their time in waters shallower than $10 \mathrm{~m}$, infrequently diving to depths $>200 \mathrm{~m}$ (Eckert \& Stewart 2001), perhaps related to constraints imposed by the oxygen minimum layer.

\section{Geographic range}

Mobula japanica utilizes a broad geographic range including both coastal and pelagic waters. The most important habitats for the tagged $M$. japanica were the southern Gulf of California, the Pacific coastal waters of Baja California Sur and the pelagic waters between the Revillagigedos Islands and Baja California. These waters are also a focal area for a number of top predators including sharks, whales, sea turtles and tuna (Block et al. 2011). The co-occurrence of vulnerable top predators and commercial species has also led to a concentration of artisanal and industrial purse-seine fisheries in the region. These fisheries have been shown to affect other wide-ranging species such as 
sea turtles (Seminoff et al. 2002, Peckham et al. 2008). Mobulid fisheries data from this area are lacking, but similar fisheries in the Gulf of California have been shown to impose directed and bycatch mortality of mobulids (Notarbartolo-di-Sciara 1988, Bizzarro 2001, Chong-Robles 2006, Sampson et al. 2010).

The large home range and global distribution of Mobula japanica indicates that it is less susceptible to extirpation than geographically restricted species from the Gulf of California such as the totoaba Totoaba macdonaldi or vaquita Phocoena sinus (Lluch-Cota et al. 2007). However, their large home range and migratory lifestyle also means that $M$. japanica cannot be protected by means of small marine reserves and managed areas (Woodroffe \& Ginsberg 1998). Detailed genetic analysis of the global population structure of $M$. japanica is a next step towards informing the global conservation of this species.

\section{Trophic dynamics and foraging ecology}

Mobula japanica is a stenophagous predator, feeding almost exclusively upon the subtropical euphausiid Nyctiphanes simplex (Notarbartolo-di-Sciara 1988, Sampson et al. 2010). Thus, the movements of $M$. japanica are likely largely driven by seasonal and geographic patterns in the availability of $N$. simplex which show strong correlations with the warmer subtropical to tropical water masses along the Pacific Coast of Baja Peninsula year-round (Brinton \& Townsend 2003). Inside the southern Gulf of California, $N$. simplex abundance peaks during spring with wind and tidally driven upwelling, and then decreases into summer (Brinton \& Townsend 1980, de Silva-Dávila \& Palomares-García 1998). In the Pacific, on the coastal shelf of Bahia Magdalena, N. simplex abundance also peaks during late spring and summer during enhanced coastal upwelling and declines when temperatures increase during autumn (Gómez-Gutiérrez et al. 1996). M. japanica have largely moved out of the Gulf of California by July, corresponding of the seasonal decline to $N$. simplex in the Gulf late in the spring and increasing abundance off southwestern Baja California in June and July (Gómez-Gutiérrez et al. 1996, de Silva-Dávila \& Palomares-García 1998). Warm tropical water intrudes into the southwestern Baja California region in late summer or early fall, leading to steep declines in N. simplex abundance (de Silva-Dávila \& Palomares-García 1998). Our tags were not retained long enough on the rays to track their response to these declines, but we speculate that they move to other regions of higher local productivity at that time.

In filter-feeding vertebrates, the energetics of foraging requires prey organisms to exceed threshold densities to make foraging profitable (Sims 1999). Basking sharks facultatively seek out habitats in which prey densities are likely to be higher (Sims et al. 2006), whereas whale sharks have been shown to feed on high densities of copepods in the Gulf of California (Clark 1997, Hacohen-Domene et al. 2006) as well as high densities of fish spawn in Belize (Heyman et al. 2001). Blue whales Balaenoptera musculus are able to access high densities of euphausiids in regions where upwelling occurs near steep topographic relief (Croll et al. 1998). Although estimates of this density threshold have not been made for mobulid rays, it is likely that they cannot sustain themselves where zooplankton occur at low densities and must take advantage of regions where physical or biological processes aggregate their prey. Anderson et al. (2011) found that migrations of Manta alfredi in the Maldives are driven by zooplankton abundance, supported by seasonal increases in primary production on the downstream sides of the atolls, which is driven by annual patterns of monsoon-driven currents. Thus, the large-scale movement patterns of Mobula japanica are likely best explained by seasonal patterns in euphausiid availability combined, perhaps, with limitations imposed by water temperature in the upper 5 to $10 \mathrm{~m}$ of the water column.

\section{Conservation and management}

The Gulf of California and the adjacent Pacific coastal waters of Baja California Sur comprise a highly complex system with a diversity of fisheries presenting multiple challenges for management (Lluch-Cota et al. 2007). Both small-scale artisanal and large-scale commercial fisheries in the region induce extensive directed or bycatch mortality on a range of long-lived species susceptible to overexploitation (Chong-Robles 2006, Peckham et al. 2008, Bizzarro et al. 2009, Galván-Magaña 2009). Mobula japanica is exceptionally vulnerable to fisheries overexploitation because of its delayed maturity and low reproductive rates (White et al. 2006). Although their targeted take is prohibited in Mexico (NOM-029PESC 2004), illegal artisanal-targeted mortality as well as substantial artisanal and large-scale fisheries bycatch mortality persist (D. A. Croll pers. obs.). Our 
information on the seasonal movements and habitat preferences of mobulid rays provides data needed for the development of effective fisheries management policies for mobulids. There are a number of marine protected areas in the Gulf of California (Lluch-Cota et al. 2007), but these are far smaller than the home range of $M$. japanica as demonstrated by our study. Therefore, marine protected areas are unlikely to provide significant protection from fisheries. Instead, the enforcement of current for the rays species-based protection combined with additional policies that reduce mobulid bycatch are likely to be the best policies to avoid catastrophic decline of this charismatic species.

Acknowledgements. We thank the Cuevas family, particularly Juan Pablo, Felipe and Juan, of El Pardito Island, Baja California Sur, for their field assistance, friendship and hospitality. Juan Jesus Lucero and James Schultz provided additional logistical support and hospitality. Dr. Ellen Freund provided early conceptual assistance for the study. Dr. Steven Teo provided important assistance for data analysis. Dr. Bernie Tershy provided valuable manuscript review. The Monterey Bay Aquarium provided funding for the study. F.G.-M. received fellowships from Instituto Politécnico Nacional (COFAA and EDI). The study was conducted under Mexican CONAPESCA-SAGARPA permit no. DGOPA.02904.260410.-1490 and no. 160401-61303 to F.G.-M.

\section{LITERATURE CITED}

Alexander R (1996) Evidence of brain warming in the mobulid rays, Mobula tarapacana and Manta birostris (Chondrichthyes: Elasmobranchii: Batoidea: Myliobatiformes). Zool J Linn Soc 118:151-164

> Anderson RC, Adam MS, Goes JI (2011) From monsoons to mantas: seasonal distribution of Manta alfredi in the Maldives. Fish Oceanogr 20:104-113

Bizzarro J (2001) The occurrence of mobulid (Chondrichthyes: Mobulidae) rays in the Gulf of California and their associated fisheries. Technical report prepared for Monterey Bay Aquarium, Monterey, CA

Bizzarro JJ, Smith WD, Hueter RE, Tyminski J and others (2009) The status of shark and ray fishery resources in the Gulf of California: applied research to improve management and conservation. Moss Landing Marine Laboratories Technical Publication, 09-01

Block BA, Dewar H, Farwell C, Prince E (1998a) A new satellite technology for tracking the movements of Atlantic bluefin tuna. Proc Natl Acad Sci USA 95:9384-9389

Block BA, Dewar H, Williams T, Prince E, Farwell C, Fudge D (1998b) Archival tagging of Atlantic bluefin tuna (Thunnus thynnus thynnus). Mar Technol Soc J 32:37-46

Block BA, Jonsen I, Jorgensen S, Winship A and others (2011) Tracking apex marine predator movements in a dynamic ocean. Nature 475:86-90

Brinton E (1967) Vertical migration and avoidance capability of euphausiids in the California Current. Limnol Oceanogr 12:451-483
Brinton E, Townsend AW (1980) Euphausiids in the Gulf of California - the 1957 cruises. CCOFI Rep XXI:211-236

Brinton E, Townsend A (2003) Decadal variability in abundances of the dominant euphausiid species in southern sectors of the California Current. Deep-Sea Res II 50: 2449-2472

Chong-Robles J (2006) Análisis de la captura incidental de elasmobranquios en la pesquería mexicana de atún con red de cerco en el Océano Pacífico Oriental. CICESE. MSc thesis, CICESE, Ensenada, Baja California

Clark E (1997) Young whale sharks, Rhincodon typus, feeding on a copepod bloom near La Paz, Mexico. Environ Biol Fishes 50:63-73

Croll DA, Tershy BR, Hewitt RP, Demer DA and others (1998) An integrated approach to the foraging ecology of marine birds and mammals. Deep-Sea Res II 45: 1353-1371

> Croll DA, Acevedo-Gutiérrez A, Tershy BR, Urbán-Ramírez $\mathrm{J}$ (2001) The diving behavior of blue and fin whales: is dive duration shorter than expected based on oxygen stores? Comp Biochem Physiol A Mol Integr Physiol 129: 797-809

> DeLong R, Stewart B, Hill R (1992) Documenting migrations of northern elephant seals using day length. Mar Mamm Sci 8:155-159

de Silva-Dávila R, Palomares-García JR (1998) Unusual larval growth production of Nyctiphanes simplex in Bahía de La Paz, Baja California Sur, México. J Crustac Biol 18: 490-498

- Eckert SA, Stewart BS (2001) Telemetry and satellite tracking of whale sharks, Rhincodon typus, in the Sea of Cortez, Mexico, and the north Pacific Ocean. Environ Biol Fishes 60:299-308

Ekstrom P (2002) Automated threshold-free geolocation from light. In: Bigelow K, Chang R (eds) Proceedings of the 53rd Annual Tuna Conference. Southwest Fisheries Science Center, NMFS and the Inter-American Tropical Tuna Commission, Lake Arrowhead, CA, p 14

Eschmeyer W, Herald E, Hammann H (1983) A field guide to pacific coast fishes. Houghton Mifflin, New York, NY

Galván-Magaña F (2009) La pesquería de tiburones en Baja California Sur. In: Urciaga Garcia JI, Beltrán Morales LF, Lluch Belda D (eds) Recursos marinos y servicios ambientales en el desarrollo regional. Centro de Investigaciones Biológicas del Noroeste, La Paz, BCS, p 227-244

Gilly WF, Markaida U, Baxter CH, Block BA and others (2006) Vertical and horizontal migrations by the jumbo squid Dosidicus gigas revealed by electronic tagging. Mar Ecol Prog Ser 324:1-17

Gómez-Gutiérrez J, De Silva-Dávila R, Lavaniegos-Espejo B (1996) Growth production of the euphausiid Nyctiphanes simplex on the coastal shelf off Bahía Magdalena, Baja California Sur, México. Mar Ecol Prog Ser 138:309-314

Gómez-Gutiérrez J, Tremblay N, Martínez-Gómez S, Robinson CJ, Del Ángel-Rodríguez J, Rodríguez-Jaramillo C, Zavala-Hernández C (2010) Biology of the subtropical sac-spawning euphausiid Nyctiphanes simplex in the northwestern seas of Mexico: vertical and horizontal distribution patterns and seasonal variability of brood size. Deep-Sea Res II 57:606-615

Gunn J, Polacheck T, Davis T, Sherlock M, Betlehem A (1994) The development and use of archival tags for studying the migration, behaviour and physiology of southern bluefin tuna, with an assessment of the poten- 
tial for transfer of the technology to groundfish research. ICES Mini Symposium on Fish Migration, ICES, Copenhagen, p 23

Hacohen-Domene A, Galvan-Magana F, Ketchum-Mejia J (2006) Abundance of whale shark (Rhincodon typus) preferred prey species in the southern Gulf of California, Mexico. Cybium 30:99-102

- Heyman WD, Graham RT, Kjerfve B, Johannes RE (2001) Whale sharks Rhincodon typus aggregate to feed on fish spawn in Belize. Mar Ecol Prog Ser 215:275-282

Hill R (1994) Theory of geolocation by light levels. In: Le Boeuf B, Laws R (eds) Elephant seals: population ecology, behavior, and physiology. University of California Press, Berkeley, CA, p 227-236

Hill R, Braun M (2001) Geolocation by light-level, the next step: latitude. In: Sibert J, Nielsen JL (eds) Electronic tagging and tracking in marine fisheries. Kluwer Academic Publishers, Dordrecht, p 315-330

Hobro F (2002) The feeding ecology, foraging behaviour and conservation of manta rays (Mobulidae) in Baja California, Mexico. MSc thesis, University of Wales, Bangor

Hochachka PW, Somero GN (2002) Biochemical adaptation: mechanism and process in physiological evolution. Oxford University Press, New York, NY

Hooge PN, Eichenlaub B (1997) Animal movement extension to ArcView. Alaska Science Center, Biological Science Office, US Geological Survey, Anchorage, AK

IUCN (2012) IUCN Red List of Threatened Species. Version 2012.1. <www.iucnredlist.org>. Downloaded 7 June 2012

Lluch-Cota SE, Aragon-Noriega EA, Arreguin-Sanchez F, Aurioles-Gamboa D and others (2007) The Gulf of California: review of ecosystem status and sustainability challenges. Prog Oceanogr 73:1-26

Musyl MK, Brill RW, Curran DS, Gunn JS and others (2001) Ability of archival tags to provide estimates of geographical position based on light intensity. In: Sibert JR, Nielsen JL (eds) Electronic tagging and tracking in marine fishes. Kluwer Academic Publishers, Dordrecht, p 89-108

National Geophysical Data Center (2001) 2-minute Gridded Global Relief Data (ETOPO2). US Department of Commerce, National Oceanic and Atmospheric Administration, National Geophysical Data Center, available at http://www.ngdc.noaa.gov/mgg/fliers/06mgg01.html

Nielsen A, Bigelow KA, Musyl MK, Sibert JR (2006) Improving light-based geolocation by including sea surface temperature. Fish Oceanogr 15:314-325

NOM-029-PESC (2004) Proyecto de Norma Oficial Mexicana pesca responsable de tiburones y rayas. Especificaciones para su aprovechamiento. Available at http:// gaceta.cicese.mx/gaceta/111/projec_NOM-029-PESC2006.pdf

Editorial responsibility: Jake Rice, Ottawa, Canada
Notarbartolo-di-Sciara G (1988) Natural-history of the rays of the genus Mobula in the Gulf of California. Fish Bull 86:45-66

Pawlowicz R (2006) M_Map: a mapping package for Matlab. Available at www.eos.ubc.ca/ rich/map.html

Peckham SH, Maldonado-Diaz D, Koch V, Mancini A, Gaos A, Tinker MT, Nichols WJ (2008) High mortality of loggerhead turtles due to bycatch, human consumption and strandings at Baja California Sur, Mexico, 2003 to 2007. Endang Species Res 5:171-183

Sampson L, Galván-Magaña F, De Silva-Dávila R, AguíñigaGarcía S, O'Sullivan JB (2010) Diet and trophic position of the devil rays Mobula thurstoni and Mobula japanica as inferred from stable isotope analysis. J Mar Biol Assoc UK 1:1-8

Seminoff JA, Resendiz A, Nichols WJ (2002) Home range of green turtles Chelonia mydas at a coastal foraging area in the Gulf of California, Mexico. Mar Ecol Prog Ser 242: 253-265

Serrano-López JN (2009) Estudio comparative de la reproduccion de tres especies del genero Mobula (Chondrichthyes: Mobulidae) en el suroeste del Golfo de California, Mexico. MSc thesis, Centro Interdisciplinario de Ciencias Marinas, La Paz, BCS

Silverman B (1986) Density estimation for statistics and data analysis. Chapman \& Hall, London

Sims DW (1999) Threshold foraging behaviour of basking sharks on zooplankton: life on an energetic knife-edge? Book 266. The Royal Society, London

Sims DW, Witt MJ, Richardson AJ, Southall EJ, Metcalfe JD (2006) Encounter success of free-ranging marine predator movements across a dynamic prey landscape. Proc Biol Sci 273:1195-1201

Teo SLH, Boustany A, Blackwell S, Walli A, Weng KC, Block BA (2004) Validation of geolocation estimates based on light level and sea surface temperature from electronic tags. Mar Ecol Prog Ser 283:81-98

Villavicencio-Garayzar CJ (1991) Observations on Mobula munkiana (Chondrichthyes: Mobulidae) in the Bajia de la Paz, B.C.S., Mexico. Rev Invest Cient 2:78-81

Welch DW, Eveson JP (1999) An assessment of light-based geoposition estimates from archival tags. Can J Fish Aquat Sci 56:1317-1327

White WT, Giles J, Dharmadi, Potter IC (2006) Data on the bycatch fishery and reproductive biology of mobulid rays (Myliobatiformes) in Indonesia. Fish Res 82:65-73

Woodroffe R, Ginsberg JR (1998) Edge effects and the extinction of populations inside protected areas. Science 280:2126

Wormley S (2007) GPS errors and estimating your receiver's accuracy. Available at www.edu-observatory.org/gps/ gps_accuracy.html

Submitted: August 15, 2011; Accepted: June 26, 2012

Proofs received from author(s): September 20, 2012 